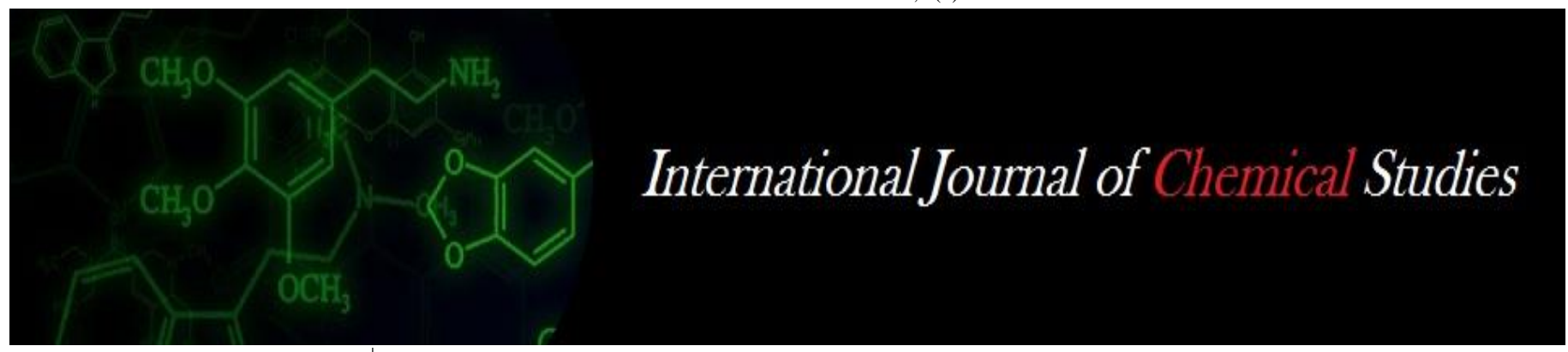

P-ISSN: 2349-8528

E-ISSN: 2321-4902

www.chemijournal.com

IJCS 2020; 8(4): 1845-1848

(C) 2020 IJCS

Received: 16-05-2020

Accepted: 17-06-2020

HP Sankhyan

Principal Scientist/ Professor (Forestry) Department of Tree Improvement and Genetic Resources, College of Forestry, Dr YS Parmar University of

Horticulture and Forestry,

Nauni-Solan, Himachal Pradesh, India

Sanjeev Thakur

Professor and Head (Forestry),

Department of Tree Improvement and

Genetic Resources, College of Forestry,

Dr YS Parmar University of

Horticulture and Forestry,

Nauni- Solan Himachal Pradesh, India

Sunil Kumar

Field Assistant, Department of Tree

Improvement and Genetic Resources,

College of Forestry,

Dr YS Parmar University of

Horticulture and Forestry,

Nauni- Solan Himachal Pradesh, India

Karishma

Field Assistant, Department of Tree

Improvement and Genetic Resources,

College of Forestry,

Dr YS Parmar University of

Horticulture and Forestry,

Nauni- Solan, Himachal Pradesh, India

Prachi

Data Operator, Department of Tree

Improvement and Genetic Resources,

College of Forestry,

Dr YS Parmar University of

Horticulture and Forestry,

Nauni- Solan, Himachal Pradesh, India

Krishan Chand

Scientist (Agroforestry), Department of Silviculture and Agroforestry, College of Forestry, Dr YS Parmar University of Horticulture and Forestry, Nauni- Solan Himachal Pradesh, India
Corresponding Author: HP Sankhyan

Principal Scientist/ Professor (Forestry) Department of Tree Improvement and Genetic Resources, College of Forestry, Dr YS Parmar University of

Horticulture and Forestry,

Nauni-Solan, Himachal Pradesh, India

\section{Morphological characteristics among different populations for screening of beul trees (Grewia optiva Drummond)}

\author{
HP Sankhyan, Sanjeev Thakur, Sunil Kumar, Karishma, Prachi and \\ Krishan Chand
}

DOI: https://doi.org/10.22271/chemi.2020.v8.i4s.9896

\begin{abstract}
Morphological characteristics among 15 populations for screening of beul trees (Grewia optiva) have been studied in 3 districts viz; Solan', Sirmaur, and Una of Himachal Pradesh (between 20-30 cm diameter class) growing on cropland situation. On study the qualitative, quantitative and pseudo quantitative characteristics and on the basis of overall scoring index of useful desired traits, the population site SL1 $(1540 \mathrm{~m}$ a $\mathrm{msl})$ in districts Solan has proved the best population, whereas the population site SM2 (1763m a msl) in district Sirmour and the population site UN5 $(510 \mathrm{~m}$ a msl) in district Una are at par and both are ranked at number 2 . All the populations varied statistically significant in all the desired morphological traits, i.e., plant growth, leaf, fruits and seeds characteristics. The populations viz; Kothi Kunal (SL1), Jajjer (SM2) and Lamlehri (UN5) are significantly proved the best sources, on the basis of natural phenotypical observations, for selection and screening of superior individuals within the populations, so as to develop beul based agroforestry in uplands of Himachal Pradesh.
\end{abstract}

Keywords: Grewia optiva, morphological characteristics, variation, fodder quality parameters, diameter class, cropland, Beul, population

\section{Introduction}

Grewia optiva Drummond (Beul) is one of the most important tree species used as fodder in Himachal Pradesh (Singh, 2005) ${ }^{[14]}$. It belongs to family Tiliaceae and naturally distributed in India, Bhutan, Nepal, and Pakistan. In India, it is distributed in areas of Himachal Pradesh, Jammu \& Kashmir, Punjab, Sikkim, and Uttar Pradesh (Hooker, 1875) ${ }^{[7]}$. Grewia optiva Drummond is commonly known as 'Beul' and very popular agroforestry trees, which is grown in low and mid hills regions in the Western and Central Himalaya on account of its utility as fodder, fuel and fiber (Coleman 1982) ${ }^{[5]}$. Grewia optiva is a small to medium sized deciduous tree, 5-12 $\mathrm{m}$ in height; crown spreading; bole clear, 3-4 $\mathrm{m}$ and about $1 \mathrm{~m}$ in diameter. Branches smooth pale silvery brown; bark dark brown, thick and roughish, exploiting in small woody scales. Leaves opposite, ovate, acuminate, closely serrate, rough and hairy. Fruit is a drupe, 14 locked, olive green and black when ripe (Troup, 1921) ${ }^{[15]}$. Leaves are shed in March and April and new ones appear in the month of April to May. The fruits are formed soon after and attain full size by September, ripening between October to December. The fruits are born on previous year's shoots. The first pre-requisite step to undertake breeding programme and to obtain improved genetic gain is selection of best population and best individuals within the population. Hence, present study was undertaken to study variation in morphological characteristics among different populations to select plus trees of Grewia optiva Drummond, so as to develop beul based agroforestry models in uplands of Himachal Pradesh and also to obtain improved genetic gain.

\section{Materials and Methods}

The study on Grewia optiva Drummond (Beul) has been undertaken in low and mid hills zones at different sites of Himachal Pradesh. In the first phase, the study was carried out in district Solan, Sirmour and Una, keeping in view the rich genetic diversity and phenotypically 
superior plant populations of Grewia optiva. The criteria of selection of superior plants within the 15 populations was 20$30 \mathrm{~cm}$ diameter class. The population includes 6 phenotypically superior plants on the same site, which is identified, marked and data is presented as mean value of 6 superior plus trees in the population. Variation in leaf characteristics, plant characteristics, fruit and seed characteristics among different populations were undertaken as per standard methodology suggested by (Robinson et al. 1951) ${ }^{[12]}$ and (Al- Jibouri et al. 1958) ${ }^{[1]}$. The variation in leaf characteristics (leaf length in $\mathrm{cm}$, leaf width in $\mathrm{cm}$, leaf area in $\mathrm{cm}^{2}$, leaf petiole length in $\mathrm{cm}$, fresh weight of 100 leaves in $\mathrm{g}$ and dry weight of 100 leaves in $\mathrm{g}$ ), plant characteristics (plant height in $\mathrm{m}$, plant diameter in $\mathrm{cm}$, plant crown/spread in $\mathrm{m}$, number of primary branches, number of secondary branches and primary branches angles) and fruit measurement characteristics (fresh weight of 100 fruits in g, dry weight of 100 fruits in $\mathrm{g}$, fruit length in $\mathrm{mm}$, fruit width in $\mathrm{mm}$ and fruit thickness in $\mathrm{mm}$ ) were as per method adopted by (Kaushal PS.1978) [9]. Data has been analyzed statistically as per method suggested by (Panse and Sukhatme, 1967) ${ }^{[10]}$ and (ISTA 1966) ${ }^{[8]}$. The table of analyses of variance (ANOVA) was set and used as explained by (Gomez 1984) ${ }^{[6]}$. Altitude of the populations ranged from $395 \mathrm{~m}$ a $\mathrm{msl}$ to $1978 \mathrm{~m}$ a $\mathrm{msl}$ in the study area, named as low and mid hill zones at different sites of Himachal Pradesh. Altitude of the populations were taken using GPS.

\section{Results and Discussion}

To study the variation in leaf, plant growth and fruit and seeds characteristics, all the qualitative, quantitative and pseudo qualitative characteristics have been recorded, on the basis of overall scoring index of useful and desired characteristics. The population sites Kothi Kunal (SL1, 1540m a msl) has been considered and found as the best population. Whereas the population site, Jajjer (SM2, 1763m a msl) and population site Lamlehri (UN5, 510m a msl) parameters and other morphological characteristics are at Stastically par. These are the sources/populations, which are most appropriate for fodder quality among all other populations in order to obtain improved genetic gain and to develop beul based agroforestry in uplands of Himachal Pradesh. These three populations are statistically significant and the best one over other populations under study (Table 1-3) and proved best sources, on the basis of natural phenotypical observation on desired and useful traits.

Result presented in Table 1 revealed the variation in leaf characteristics viz., leaf length ranged from $15.87 \mathrm{~cm}-8.94$ $\mathrm{cm}$; leaf width ranged from $9.88 \mathrm{~cm}-5.36 \mathrm{~cm}$; leaf area ranged from $123.49 \mathrm{~cm}^{2}-44.95 \mathrm{~cm}^{2}$; leaf petiole length from $1.54 \mathrm{~cm}-0.84 \mathrm{~cm}$; fresh weight of 100 leaves from $167.17 \mathrm{~g}$ $63.00 \mathrm{~g}$ and dry weight of 100 leaves ranged from $60.22 \mathrm{~g}-$ $28.00 \mathrm{~g}$ among different populations (between $20-30 \mathrm{~cm}$ diameter class) growing on cropland situation of the selected sites. As depicted in Table 2, the plant characteristics viz., plant height ranged from $9.54 \mathrm{~m}-3.85 \mathrm{~m}$; plant diameter ranged from $33.62 \mathrm{~cm}-12.67 \mathrm{~cm}$; plant crown/spread ranged from $5.08 \mathrm{~m}-1.86 \mathrm{~m}$; number of primary branches ranged from $6.67-2.83$; number of secondary branches ranged from $13.00-3.00$ and plant primary branch angle ranged from $94.17^{0}-9.50^{\circ}$ among different populations (between $20-30$ $\mathrm{cm}$ diameter class) growing on cropland situation of the selected sites. Table 3 explains the variation in fruit measurement characteristics viz., fresh weight of 100 fruits ranged from $23.31 \mathrm{~g}-20.01 \mathrm{~g}$; dry weight of 100 fruits ranged from $15.44 \mathrm{~g}-12.27 \mathrm{~g}$; fruit length ranged from 6.25 $\mathrm{mm}-5.50 \mathrm{~mm}$; fruit width ranged from $5.10 \mathrm{~mm}-4.61 \mathrm{~mm}$ and fruit thickness ranged from $5.40 \mathrm{~mm}-4.32 \mathrm{~mm}$ among different populations (between $20-30 \mathrm{~cm}$ diameter class) on cropland situations of research working area in Himachal Pradesh under the study.

Table 1: Morphological variation in leaf characteristics among different populations of Grewia optiva Drummond (Beul)

\begin{tabular}{|c|c|c|c|c|c|c|c|c|c|}
\hline Districts & $\begin{array}{c}\text { Population } \\
\text { Code }\end{array}$ & $\begin{array}{l}\text { Population } \\
\text { Site }\end{array}$ & $\begin{array}{c}\text { Population Altitude } \\
\text { Above Mean Sea } \\
\text { Level (m) }\end{array}$ & $\begin{array}{l}\text { Leaf Length } \\
(\mathrm{cm})\end{array}$ & $\begin{array}{c}\text { Leaf Width } \\
(\mathrm{cm})\end{array}$ & $\begin{array}{l}\text { Leaf Area } \\
\left(\mathrm{cm}^{2}\right)\end{array}$ & $\begin{array}{l}\text { Leaf Petiole } \\
\text { Length }(\mathrm{cm})\end{array}$ & \begin{tabular}{|c|} 
Fresh Weight \\
of 100 \\
Leaves $(\mathrm{g})$
\end{tabular} & $\begin{array}{l}\text { Dry Weight } \\
\text { of } 100 \\
\text { Leaves }(\mathrm{g})\end{array}$ \\
\hline \multirow{5}{*}{ Solan } & SL1 & Kothi Kunal & 1540 & 15.87 & 9.88 & 123.49 & 1.45 & 163.78 & 42.56 \\
\hline & SL2 & Uncha Gaon & 1978 & 15.52 & 9.30 & 101.02 & 1.42 & 160.11 & 45.56 \\
\hline & SL3 & Neri Kalan & 1525 & 13.92 & 7.95 & 76.60 & 0.99 & 122.56 & 38.72 \\
\hline & SL4 & Gaddo & 1265 & 14.18 & 8.25 & 95.52 & 1.36 & 123.06 & 43.89 \\
\hline & SL5 & Devra & 1050 & 13.32 & 8.37 & 79.51 & 1.54 & 112.78 & 37.50 \\
\hline \multirow{5}{*}{ Sirmaur } & SM1 & Machher & 882 & 12.98 & 7.16 & 84.75 & 0.95 & 90.89 & 36.28 \\
\hline & SM2 & Jajjer & 1763 & 14.60 & 8.14 & 94.08 & 1.01 & 167.17 & 60.22 \\
\hline & SM3 & Nehar Bag & 1520 & 11.81 & 7.38 & 74.68 & 0.89 & 91.11 & 28.22 \\
\hline & SM4 & Badon & 819 & 12.37 & 6.42 & 72.19 & 1.10 & 80.33 & 28.00 \\
\hline & SM5 & Dhar Kyari & 932 & 11.43 & 5.75 & 58.08 & 0.84 & 81.94 & 28.17 \\
\hline \multirow{6}{*}{ Una } & UN1 & Kant & 395 & 12.19 & 7.01 & 64.92 & 1.18 & 91.78 & 31.22 \\
\hline & UN2 & Nawami & 561 & 8.94 & 5.36 & 44.95 & 1.02 & 63.89 & 23.61 \\
\hline & UN3 & Bangana & 558 & 9.96 & 8.79 & 50.18 & 1.10 & 79.56 & 31.00 \\
\hline & UN4 & Thana kalan & 496 & 10.42 & 6.07 & 54.80 & 1.13 & 63.00 & 24.39 \\
\hline & UN5 & Lamlehri & 510 & 12.21 & 6.67 & 71.82 & 1.08 & 106.33 & 37.72 \\
\hline & $\mathrm{CD}$ & 0.05 & & 0.51 & 0.21 & 9.72 & 0.07 & 9.15 & 1.80 \\
\hline
\end{tabular}


Table 2: Morphological variation in plant characteristics among different populations of Grewia optiva Drummond (Beul)

\begin{tabular}{|c|c|c|c|c|c|c|c|c|c|}
\hline Districts & $\begin{array}{l}\text { Population } \\
\text { Code }\end{array}$ & Population & \begin{tabular}{|c|}
$\begin{array}{c}\text { Population Altitude } \\
\text { above Mean Sea } \\
\text { Level }(\mathbf{m})\end{array}$ \\
\end{tabular} & $\begin{array}{l}\text { Plant } \\
\text { Height } \\
\text { (m) } \\
\end{array}$ & $\begin{array}{c}\text { Plant } \\
\text { Diameter } \\
(\mathbf{c m}) \\
\end{array}$ & $\begin{array}{c}\text { Plant } \\
\text { Crown } \\
\text { Spread (m) } \\
\end{array}$ & $\begin{array}{c}\text { Plant Primary } \\
\text { Branches (Nos.) }\end{array}$ & \begin{tabular}{|c|} 
Plant \\
Secondary \\
Branches(Nos.)
\end{tabular} & $\begin{array}{c}\text { Plant Primary } \\
\text { Branches } \\
\text { Angle }\left(^{\circ}\right) \\
\end{array}$ \\
\hline \multirow{5}{*}{ Solan } & SL1 & Kothi Kunal & 1540 & 9.54 & 22.16 & 1.02 & 4.17 & 12.67 & \begin{tabular}{|l|}
94.17 \\
\end{tabular} \\
\hline & SL2 & Uncha Gaon & 1978 & 8.47 & 33.62 & 3.21 & 3.50 & 11.67 & 63.33 \\
\hline & SL3 & Neri Kalan & 1525 & 4.23 & 21.74 & 2.96 & 5.83 & 13.00 & 30.33 \\
\hline & SL4 & Gaddo & 1265 & 5.08 & 13.68 & 1.86 & 2.83 & 5.00 & 21.67 \\
\hline & SL5 & Devra & 1050 & 8.30 & 24.02 & 5.08 & 3.50 & 6.00 & 61.17 \\
\hline \multirow{5}{*}{ Sirmaur } & SM1 & Machher & 882 & 7.84 & 19.72 & 4.38 & 6.67 & 9.67 & 43.33 \\
\hline & SM2 & Jajjer & 1763 & 3.85 & 21.05 & 2.79 & 4.50 & 8.67 & 39.17 \\
\hline & SM3 & Nehar Bag & 1520 & 6.99 & 19.78 & 4.29 & 6.67 & 11.83 & 20.00 \\
\hline & SM4 & Badon & 819 & 4.50 & 12.67 & 3.04 & 4.00 & 3.00 & 40.83 \\
\hline & SM5 & Dhar Kyari & 932 & 4.33 & 14.47 & 2.92 & 4.17 & 5.33 & 25.83 \\
\hline \multirow{6}{*}{ Una } & UN1 & Kant & 395 & 5.50 & 16.83 & 4.17 & 5.33 & 13.83 & 25.83 \\
\hline & $\mathrm{UN} 2$ & Nawami & 561 & 5.75 & 20.57 & 3.46 & 5.83 & 13.67 & 13.83 \\
\hline & UN3 & Bangana & 558 & 5.08 & 15.03 & 3.46 & 4.67 & 12.33 & 13.67 \\
\hline & UN4 & Thana kalan & 496 & 5.38 & 13.52 & 2.54 & 4.00 & 9.50 & 12.33 \\
\hline & UN5 & Lamlehri & 510 & 6.00 & 17.42 & 3.71 & 3.17 & 7.00 & 9.50 \\
\hline & $\mathrm{CD}$ & 0.05 & & & & 0.62 & 1.20 & 1.80 & 9.30 \\
\hline
\end{tabular}

Table 3: Morphological variation in plant fruit measurement characteristics among different populations of Grewia optiva Drummond (Beul)

\begin{tabular}{|c|c|c|c|c|c|c|c|c|}
\hline Districts & $\begin{array}{l}\text { Population } \\
\text { Code }\end{array}$ & Population & $\begin{array}{c}\text { Population Altitude } \\
\text { above Mean Sea Level }\end{array}$ & $\begin{array}{c}\text { Fresh Weight of } \\
100 \text { Fruits }(g)\end{array}$ & $\begin{array}{c}\text { Dry Weight of } \\
100 \text { Fruit }(g)\end{array}$ & $\begin{array}{l}\text { Fruit Length } \\
\qquad(\mathrm{mm})\end{array}$ & $\begin{array}{l}\text { Fruit Width } \\
\quad(\mathrm{mm})\end{array}$ & $\begin{array}{c}\text { Fruit } \\
\text { Thickness } \\
(\mathbf{m m})\end{array}$ \\
\hline \multirow{5}{*}{ Solan } & SL1 & Kothi Kunal & 1540 & 22.10 & 15.44 & 6.11 & 4.74 & 4.32 \\
\hline & SL2 & Uncha Gaon & 1978 & 23.31 & 14.79 & 5.70 & 4.66 & 4.56 \\
\hline & SL3 & Neri Kalan & 1525 & 21.05 & 13.08 & 5.75 & 4.61 & 5.04 \\
\hline & SL4 & Gaddo & 1265 & 20.07 & 13.28 & 5.70 & 5.08 & 4.84 \\
\hline & SL5 & Devra & 1050 & 21.91 & 14.17 & 6.20 & 4.80 & 4.90 \\
\hline \multirow{5}{*}{ Sirmaur } & SM1 & Machher & 882 & 22.08 & 14.27 & 6.25 & 5.10 & 5.09 \\
\hline & SM2 & Jajjer & 1763 & 24.07 & 14.89 & 6.04 & 4.80 & 5.40 \\
\hline & SM3 & Nehar Bag & 1520 & 21.97 & 12.27 & 6.06 & 5.05 & 4.70 \\
\hline & SM4 & Badon & 819 & 20.04 & 12.55 & 5.60 & 4.86 & 5.01 \\
\hline & SM5 & Dhar Kyari & 932 & 20.01 & 14.08 & 5.50 & 4.93 & 4.71 \\
\hline \multirow{6}{*}{ Una } & UN1 & Kant & 395 & 21.48 & 14.65 & 6.22 & 4.90 & 4.83 \\
\hline & UN2 & Nawami & 561 & 22.83 & 14.30 & 6.10 & 5.10 & 5.30 \\
\hline & UN3 & Bangana & 558 & 21.50 & 15.01 & 6.05 & 4.71 & 4.93 \\
\hline & UN4 & Thanaklan & 496 & 22.03 & 13.09 & 5.79 & 5.07 & 5.22 \\
\hline & UN5 & Lamlehri & 510 & 20.75 & 13.69 & 5.60 & 4.79 & 4.80 \\
\hline & $\mathrm{CD}$ & 0.05 & & 1.80 & 0.70 & 0.27 & 0.16 & 0.42 \\
\hline
\end{tabular}

Similar kind of studies and results have been reported by (Bhagta 2015) ${ }^{[2]}$, (Sankhyan et al. 2019) ${ }^{[13]}$, (Bhagta et al. 2019) [3], (Sheeraz Saleem Bhat 2010) [4] and (Rathore Amandeep 1997) ${ }^{[11]}$, among the families of Grewia optiva in established open pollinated seedling seed orchard and evaluation of selected genotypes of Grewia optiva.

It is concluded that the popuation site Kothi Kunal (SL1) has been considered and found as the best population and the population site Jajjer (SM2) and Lamlehri (UN5) are statistically at par and ranked at number 2, on the basis of overall scoring index of morphological characterestics on desired and useful traits. The study concluded with the findings that population site Kothi Kunal (SL1), Jajjer (SM2) and Lamlehri (UN5) are superior among other populations, which can be used for tree improvement programme and other breeding purposes, on the basis of phenotypically superiority which will help in selection of best individuals within the population for developing seedling seed orchard/ common garden of superior families, so as to obtain improved genetic gain. The study will also help to develop 1.5 generation seedling seed orchard of Grewia optiva (Beul) and also helps to develop beul (Grewia optiva) based agroforestry in uplands of Himachal Pradesh.

\section{Acknowledgments}

The authors are very thankful to National Mission on Himalayan Studies (NMHS) G.B. Pant National Institute of Himalayan Environment and Sustainable Development (GBPNIHESD), Kosi-Katarmal, Almora-263643, Uttarakhand, India under the Ministry of Environment Forest \& Climate Change, Govt. of India, Jorbhag Road, New Delhi110003 for funding project entitled "Biological Screening, Conservation and Establishment of Gene Bank of Grewia optiva Drummond (Beul)." to this department for undertaking this present study.

\section{References}

1. AI- Jibouri HA, Miller RA, Robinson HF. Genotypic and environmental variances and Covariance's in an upland cotton across of interspecifics origin. Agronomy Journal. 1958; 50:633-637.

2. Bhagta S. Progeny evaluation of open pollinated seedling seed orchard of Grewia optiva Drummond. M.Sc. Thesis, Department of Tree Improvement and Genetic Resources, Dr. Yashwant Singh Parmar University of Horticulture and Forestry, Nauni, Solan, India, 2015.

3. Bhagta Shikha. Sankhyan HP, Sharma Dushyant, Ashine Tesfaye. Correlation and path coefficient analyses in 
Grewia optiva Drummond. International Journal of Chemical Studies. 2019, 7(3):746-749.

4. Bhat, Sheeraz Saleem. Evaluation of established open pollinated seedling seed orchard of Grewia optiva Drummond (M.Sc. Thesis). Department of Tree Improvement and Genetic Resources, Dr. Yashwant Singh Parmar University of Horticulture and Forestry, Nauni, 2010, 89.

5. Coleman. Chromosome numbers of angiosperms collected in the state of Sao Paulo. Brazilian Journal of Genetics. 1982; 5(3):533-549.

6. Gomez KA, Gomez AA. Stastical procedures for agriculture research. A Wiley- Intersiences Publication, New York. 1984, 2 ed., 680.

7. Hooker JD. Flora of the British India L. Revve \& Co., London, 1875.

8. ISTA. International rules for seed testing. Proc. Int. Seed Testing Assoc. 1966; 31:1-152.

9. Kaushal PS. Screening of beul trees (Grewia optiva) for superiour nutritative stains M.Sc. Thesis Himachal Pradesh University, 1978, 64.

10. Panse VG, Sukhatme PV. Statistical Methods for Agricultural Works. ICAR, New Delhi, 1967, 610.

11. Rathore Amandeep. Evaluation of selected genotypes of Grewia optiva. M.Sc. Thesis Dr. Y.S.P University of Horticulture and Forestry, Nauni- Solan (H.P.), 1997, 55.

12. Robinson HF. Comstock RE. Harvey PH. Genotypic and phenotypic correlation in corn and their importance in selection. Agronomy Journal. 1951; 43:282-287.

13. Sankhayan HP, Bhagta Shikha, Thakur Sanjeev. Evaluation of the half sib progenies to identify prepotency of the mother clones of Grewia optiva Drummond. Journal of Pharmacognosy and Phytochemistry 2019; 8(4):1265-1270.

14. Singh R. Survey of social economic profile of farmers and animals feed resources in the mountains of Himachal Pradesh. Himalayans Ecology. 2005; 13(2):12-15.

15. Troup RS. Silviculture of Indian Trees. Clarendroan Press Oxford. 1921; 1:164-166. 